\title{
Prophylactic coronary artery revascularisation before elective vascular surgery did not improve long term survival
}

McFalls EO, Ward HB, Moritz TE, et al. Coronary-artery revascularization before elective major vascular surgery. N Engl J Med 2004;351:2795-804.

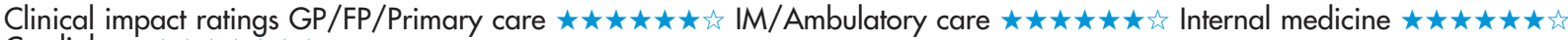
Cardiology $\star \star \star \star \star \star \star \star$ is

Q In patients with stable coronary artery disease (CAD) who are scheduled for elective major vascular surgery, does prophylactic coronary artery revascularisation reduce long term, all cause mortality?

\section{METHODS}

\begin{tabular}{|c|c|}
\hline \multirow[t]{2}{*}{ 口- } & $\begin{array}{l}\text { Design: randomised controlled trial (RCT) (Coronary Artery } \\
\text { Revascularization Prophylaxis [CARP] trial). }\end{array}$ \\
\hline & Allocation: $\{$ concealed*\}t. \\
\hline & $\begin{array}{l}\text { Blinding: blinded (\{investigators\}t and the endpoints committee } \\
\text { that validated all outcomes).* }\end{array}$ \\
\hline & Follow up period: median 2.7 years. \\
\hline & Setting: 18 Veterans Affairs medical centres in the US. \\
\hline & $\begin{array}{l}\text { Patients: } 510 \text { patients (mean age } 66 \text { y, } 98 \% \text { men) with stable } \\
\text { CAD ( } \geqslant 70 \% \text { stenosis in } \geqslant 1 \text { major coronary artery suitable for } \\
\text { revascularisation) who were scheduled for elective major } \\
\text { vascular operation for an expanding abdominal aortic aneurysm } \\
\text { or severe symptoms of arterial occlusive disease involving the } \\
\text { legs. } 65 \%(n=332 \text { ) had } \geqslant 3 \text { clinical factors for high surgical risk. } \\
62 \%(n=312) \text { received nuclear stress testing, and } 44 \% \text { ( } n=226) \\
\text { of the total population had moderate or severe defects. Exclusion } \\
\text { criteria were a need for urgent or emergency surgery, severe } \\
\text { comorbid conditions, or previous revascularisation without } \\
\text { evidence of recurrent ischaemia. }\end{array}$ \\
\hline & $\begin{array}{l}\text { Interventions: prophylactic preoperative coronary artery } \\
\text { revascularisation ( } n=258) \text { or no revascularisation }(n=252) \text {. } \\
\text { Local investigators decided whether to use percutaneous } \\
\text { coronary intervention or coronary artery bypass grafting. At } \\
\text { randomisation, stratification variables included hospital and the } \\
\text { proposed vascular surgery. }\end{array}$ \\
\hline 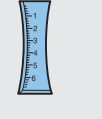 & $\begin{array}{l}\text { Outcomes: } 30 \text { day rates of myocardial infarction (MI), stroke, } \\
\text { limb loss, dialysis, and long term all cause mortality. The study } \\
\text { had } 90 \% \text { power to detect a } 10 \% \text { difference in } 3.5 \text { year survival } \\
\text { rates between groups. }\end{array}$ \\
\hline$\| \square$ & Patient follow up: $100 \%$ (intention to treat analysis). \\
\hline & $\begin{array}{l}\text { *See glossary. } \\
\text { †Information provided by author. }\end{array}$ \\
\hline
\end{tabular}

\section{MAIN RESULTS}

The groups did not differ for long term all cause mortality (table), 30 day rates of myocardial infarction, stroke, limb loss, or dialysis $(\mathrm{p}>0.05)$.

\section{CONCLUSIONS}

In patients with stable symptoms of coronary artery disease who are scheduled for elective major vascular surgery, prophylactic For correspondence. Dr E O McFalls, Minneapolis Veterans Affairs Medica Center, Minneapolis, MN, USA. mcfal001@tc.umn.edu

Source of funding: Cooperative Studies Program of the Department of Veterans Affairs Office of Research and Development. coronary artery revascularisation did not reduce long term all cause mortality.

Abstract and commentary also appear in ACP Journal Club.

Coronary artery revascularisation prophylaxis (CARP) $v$ no CARP in patients with stable coronary artery disease before elective major vascular surgery*

\begin{tabular}{lllll}
\hline $\begin{array}{l}\text { Outcome at median } \\
\text { 2.7 years }\end{array}$ & CARP & No CARP & RRR (95\% CI) & NNT \\
\hline All cause mortality & $22 \%$ & $23 \%$ & $4 \%$ & $\begin{array}{l}\text { Not } \\
\text { significant }\end{array}$ \\
\hline
\end{tabular}

*Abbreviations defined in glossary; RRR, $\mathrm{Cl}$, and NNT calculated from data in article.

\section{Commentary}

everal observational studies have suggested that preoperative coronary revascularisation before non-cardiac surgery prevents death in patients with significant CAD. ${ }^{1}$ McFalls et al have made an important contribution to perioperative medicine because they are the first to use an RCT design to evaluate whether preoperative coronary artery revascularisation before vascular surgery improves major outcomes.

Their results showing no long term mortality benefit of preoperative coronary artery revascularisation may come as a surprise to many physicians. Their results are, however, in keeping with evidence that most perioperative cardiovascular events probably originate in coronary arteries with non-haemodynamically significant stenoses (ie, $<70 \%)^{2}$

The CARP trial shows that patients receiving vascular surgery have a substantial risk of death and $\mathrm{MI} \leqslant 30$ days of surgery $(10 \%)$ and for death $(23 \%)$ during a median 2.7 years of follow up. These results highlight the need for large RCTs to identify effective interventions.

Unfortunately, strong evidence in support of prophylactic intervention (including $\beta$ blocker therapy) for preventing major cardiovascular events in patients who are receiving noncardiac surgery does not exist. ${ }^{3} 4$ Investigators need to follow the lead of McFalls et al and initiate trials to further evaluate perioperative interventions.

Based on findings from the CARP trial, physicians should avoid preoperative coronary artery revascularisation in patients with stable CAD who are receiving vascular surgery, even if a haemodynamically significant stenosis is identified by angiography or suggested by nuclear studies.

P J Devereaux, MD Claudio S Cina, MD McMaster University Hamilton, Ontario, Canada G Malaga Rodriguez, MD Hospital Nacional Cayetano Heredia Lima, Peru

1 Foster ED, Davis KB, Carpenter JA, et al. Ann Thorac Surg 1986;41:42-50. 2 Ellis SG, Hertzer NR, Young JR, et al. Am J Cardiol 1996;77:1126-8. 3 Devereaux PJ, Leslie K, Yang H. Can J Anaesth 2004;51:749-55. 4 Yang H, Raymer K, Butler R, et al. Can J Anaesth 2004;51(Supp 1):A7. 